\title{
Conceptual Framework for a Decision-Making Model to Select the Public-Private Partnership (PPP) Structure for Urban Rail Transit in Jakarta
}

\author{
Retno Ambarsari ${ }^{1}$, Sutanto Soehodho ${ }^{1}$, R Jachrizal Sumabrata ${ }^{1}$ \\ ${ }^{1}$ University of Indonesia, Faculty of Engineering, Department of Civil and Environmental Engineering \\ Margonda Raya, Depok, Indonesia \\ retno.tri91@ui.ac.id; tanto@eng.ui.ac.id; rjs@eng.ui.ac.id
}

\begin{abstract}
PPP scheme has been widely recognized as a cooperation between government and private sector to provide public service, both in developed and developing countries. In contrast with developed countries, PPP implementation faces several challenges in developing countries. Private sectors in developing countries tend to deliver an unsolicited PPP project; however, it is difficult for the government to define the appropriate PPP structure for a specific project due to lack of knowledge and experience. This paper focuses on developing a conceptual framework for a decision-making model to select the PPP structure model for urban rail transit. A clearly defined PPP structure at the early stages allows both parties' allocation of responsibility and risk. It provides exact direction on the PPP project implementation, commonly established in a long-term contract period. It is expected that the multi-criteria decision-making tools by using the AHP approach may contribute as a guideline to support decision-makers in selecting the appropriate PPP structure for urban rail transit, particularly on unsolicited PPP proposal.
\end{abstract}

Keywords: Public-private Partnership, Unsolicited Project, PPP Structure Model, Analytical Hierarchy Process, Urban Rail Transit, Sustainable Transportation

\section{Introduction}

Public-Private Partnership (PPP) has become a cooperation scheme between government and private sector accepted in many countries in the world as an alternative to developing infrastructure for public services, particularly to address the government's lack of budget and technical inability to provide and manage efficient public infrastructure services [1]-[4]. The PPP project is a government initiative and is held through a structured planning process involving a competitive tender process [5].

Policies for implementing the unsolicited PPP projects are carried out in many countries, both in developed and developing countries, such as in Australia, Chile, Colombia, Ghana, Italy, the Philippines, South Africa, and Tanzania [5]. This unsolicited project has unique attributes so that it cannot be initiated by the government, which does not require the government's support. Generally, the proposed project is not stated in the government planning document, requiring public consent. It should prioritize technological innovation in providing public services that aim to provide the infrastructure services to meet the community's basic needs and bears high-value intellectual property rights. Subsequent suggestions for business entity initiatives will be included in the government's development plan after evaluation and approval have been obtained [6], [7].

In determining whether a project is feasible to implement a PPP scheme, it is necessary to consider analyzing the risks in complex projects through an objective assessment of the government and business entities' ability to manage risks and how these can be allocated [8]. Several challenging issues are needed to address, like determining the amount of capital investment in the project [9], structuring a PPP project according to local needs [10], and designing a long-term PPP contract form for public transport projects [2]. Urban rail transit is also expected to anticipate macroeconomic changes, both from the government and business entity side [8], leading to an increase of the business entities interested in PPP project investment [11].

According to the literature review, although the PPP scheme has been introduced on wide-ranging infrastructure projects, case studies are still limited in Indonesia, particularly those related to urban rail transit infrastructure. Some literature may 
be adopted from the foreign cases but should be adjusted with the local context [10]. Measuring the success criteria and risk analysis are customized based on its project characteristics and how the stakeholders and experts adapt to the situation [12].

The conceptual framework and research methodology are developed to select an appropriate PPP structure for urban rail transit infrastructure. A literature review has been conducted to identify the critical success factor and risk related to a specific PPP project. Moreover, a pilot survey prioritizes selecting the influence success factor and risk by capturing stakeholder's perspectives. It involves local PPP experts in specific projects familiar with and can recognize the factor influencing the PPP project performance. The pilot survey result is used to set a structured decision-making model by utilizing the Analytical Hierarchy Process (AHP) approach to capture stakeholder's perspectives. The outcome is expected to deliver a generic decision-making model guideline for defining the urban rail transit project's PPP structure.

This paper reviews PPP projects' nature, its influenced factors and risks related to urban rail transit projects, and a brief description of the decision-making model using the AHP approach. This paper aims to propose a conceptual framework for selecting an appropriate PPP structure for urban rail transit projects for a specific case study.

\section{Literatur Review}

PPP terminology varies widely, where government agencies, financial institutions, academics, and concessionaires each have their definitions [13]. The government has a central role in determining the implementation of the PPP scheme in a public service sector because the government has an interest in social and political implications as well as a strong political will for PPP projects [14], [15].

From various definitions, the PPP scheme, in general, has the same aspects. Those describe the relationship management between the government and private sectors in providing public service. The PPP scheme also introduces a paradigm shift from previously oriented towards asset creation to delivering public service with a transfer of significant risk to the private sector and remuneration of payments in exchange for the private sector's services [9], [13].

\subsection{Unsolicited Proposal in the PPP Scheme}

An alternative development of this scheme is an unsolicited proposal or defined as an initial proposal from the business entity. This proposal is a new approach to PPP project implementation that involves initiatives from the business entity as an investor to identify and propose a public service to the government. The fundamental difference between solicited and unsolicited project is that unsolicited projects cannot receive support from the government, which means they must be financially viable [5].

The model for the proposed initiative for the PPP scheme provides an opportunity for the government to obtain better technical assistance from the private sector. The private sector can identify and prioritize projects by conducting a prefeasibility study, introducing innovations and technologies, and an early indication of market interest in the proposed project [5]. On the other hand, the government faces several challenges, such as the government's lack of technical capacity to assess, prepare, and carry out PPP projects. These include managing project proposals and anticipating fiscal burdens, limited market for projects proposed on an initiative to reduce competition, and the possibility of corruption [8], [16], [17].

\subsection{The Generic PPP Structure}

Conceptually, PPP is a combination of roles between the government and the private sector. The fundamental difference between implementing a conventional contract with the PPP between the government and business entities is that the contract duration can reach more than 30 years to build, manage, and maintain assets. When the contract duration ends, the assets convert to government property [2], [3], [18], [19]. PPP structure development is necessary as a guide for policymakers; therefore, it is important to identify each party's roles and interactions in the PPP projects [10].

Variations on PPP structures are based on various factors, such as the type of PPP project [1], [14], demographic conditions and population density [9], and division of roles between the government and business entities in the PPP sector or project [20]. Build-Operate-Transfer (BOT), Build-Owned-Operate-Transfer (BOOT), Design-Build-Finance-Operate (DBFO), Design-Construct-Manage-Finance (DCMF), IPP, Build-Owned-Operate (BOO), Design-Build-Finance-Maintain (DBFM) are typical schemes known in the application of the PPP concept [1]-[3], [8], [14], [18], [21], [22]. The PPP 
structure approach is generally applied to the transportation sector are Design-Build-Operate-Transfer and Build-OperateTransfer [23].

\subsection{The PPP Key Success Factor}

Based on the PPP schemes worldwide, several critical factors that affect PPP projects' success have been identified, which includes the government's political support and acceptance to private investment [1], [11], [24]-[27]. Stable political conditions, supporting existing legal and policy frameworks, and a strongly committed person in charge of collaborative projects also influence factors.

Other factors are also essential and determinant in PPP projects, including how risk is allocated between the government and business entity and risk mitigation related to risk costs. Experience in urban rail transit development for urban areas often fails to attract a significant investment due to demand uncertainty [1], [11], [24], [28]. Stakeholders should pay more attention to the critical success factors of the PPP implementation; thus, creating the formulation of a PPP management framework in urban rail transit projects with full consideration is essential [4].

\subsection{Role and Risk Sharing Between the Government and Private Sector}

As previously described, the first aspect determining a PPP project is the cooperation between the government and business entities [13], [29]. The PPP structure defines the roles between the government and private sectors. It is closely related to both parties' motivation and reason, explaining how the PPP option is chosen to determine its participation level [30]. Issues identification between both parties should be translated into transparent, accountable, balanced, and consistent contractual ties to protect both party's interests [13], [15]. PPP projects are successful if the service quality meets the contract specification. Moreover, its performance measures are conducted according to the contract provisions [8], [31].

PPP project management's risk starts from the planning stage to the transfer of assets at the end of the concession period [32]. However, the most considerable risk occurs at the operational phase [26]. These risks represent a form of interdependence between the government and business entities that tend to have high complexity, especially in PPP projects [8], [10], [33]. The difference in perspective and attitudes between the two parties makes risk-sharing difficult because of different goals [15], resulting in different acting ways [34]. Risk management in the PPP scheme becomes an effective strategy for transferring project risk to business entities through careful contract design that can map all the risks inherent in each component of project tasks and determine how to manage them [8].

The main risks that business entities consider in the urban rail-based transportation sector are income risk, passenger demand risk, and ridership, risks associated with planning and design, financing, operational, and performance of assets that influence the financial condition of a business entity [3], [8], [35], [36]. Furthermore, the risk of passenger demand and currency exchange rates, especially in rail-based transportation infrastructure projects with PPP schemes, are risks that are often identified [8], [36]-[39].

\subsection{Analytical Hierarchy Process}

Analytic Hierarchy Process (AHP) is a method used to compare pairs of criteria and alternative solutions to obtain a systemic ranking representing rational decisions [40], [41]. The method developed by Thomas L. Saaty in the 1970s is a decision-making method by considering the factors of logic, intuition, experience, knowledge, emotion, and perception to be optimized in a systematic process [42]. Data analysis in this method allows the decision-making process to be undertaken by considering a combination of qualitative and quantitative criteria (multi-criteria analysis) [43]. This approach method is very practical and extensive, suitable for solving problems with a certain level of complexity, and requires strategic solutions in a greater scientific field [42], [44].

By far, the AHP method has been used in several relevant scientific studies, such as to determine the type of toll road financing with the most feasible PPP scheme in Iran, to conduct a risk assessment at the construction stage, and risk management in wind energy projects [45]-[47]. Moreover, related research in the transport sector used the AHP to select the best PPP model for airport development projects as decision-making tools have also been undertaken [12]. It emphasizes that the AHP method can develop and adapt according to the times and is effectively used as a decision-making tool. As 
shown in Figure 1, the AHP structure is designed for specific urban rail transit and comprises four stages: the goals, decisionmakers, criteria, and alternatives.

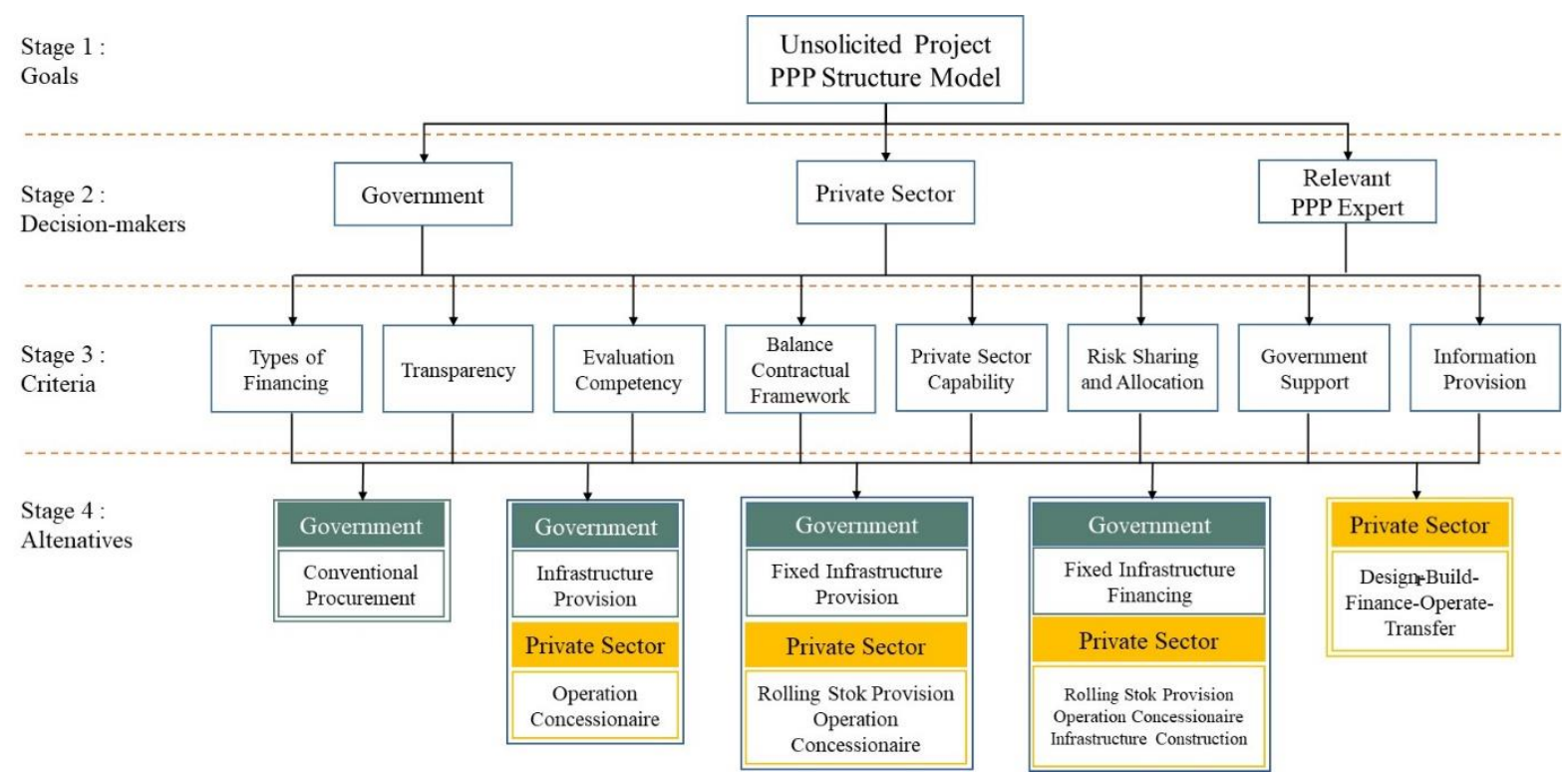

Fig. 1: AHP Structure Development

\section{Methodology}

Based on the problem's formulation and this study's objectives, a research design is prepared, referring to several studies as references. This research combines several research types, such as quantitative research methods with a literature study approach, case studies, and testing decision-making, using multi-tool AHP's decision-making criteria.

The literature study approach was carried out to obtain research variables related to the PPP application on urban transit rail. These variables are verified according to the corresponding case study's implementation conditions. The decision-making approach is adopted from a conceptual framework used in research to select PPP models for airports. The case study is the unsolicited proposal of Jakarta LRT project Kebayoran Lama - Pulo Gadung, which currently has received approval from the Provincial Government of DKI Jakarta. The PPP structure determination is essential to define the relationship between both parties and proposed to the Provincial Government of DKI Jakarta.

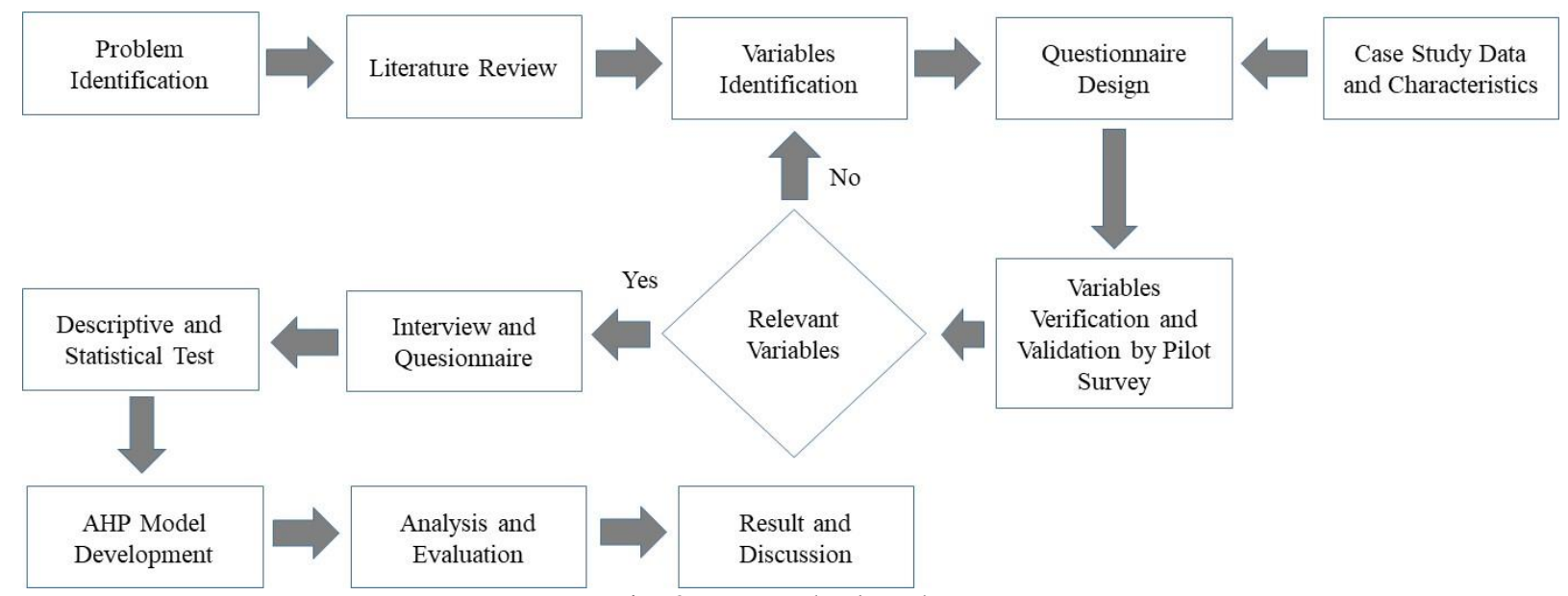

Fig. 2: Research Flowchart 
As illustrated in Figure 2, the research design describes a step-by-step approach, particularly emphasizing the identification of research variables, verification, and validation with relevant PPP experts to select the appropriate variables then tested in the pilot survey. Statistical analysis is performed on the process. Those selected variables are then linked and used as input on the AHP model. The AHP model is developed as the Multi-Criteria Decision Making (MCDM) method to evaluate pairwise comparison variables. The criteria and the alternative from the final step will be analyzed to obtain the appropriate result.

\section{Result and Discussion}

The conceptual framework is designed to provide direction and assistance to the researchers to research a systematic flow. It is a unique model constructed for specific research in approaching an existing theory to adapt the research objectives. The conceptual framework is usually positioned in the discussion within the literature review. It consists of interconnected concepts capable of explaining their relationships, and many researchers used this concept to answer defined problems [48]. A specific conceptual framework is developed for this research. It covers a step-by-step approach from identification, concept design, related data collection, AHP model development to analysis and evaluation shown in Figure 3 below.

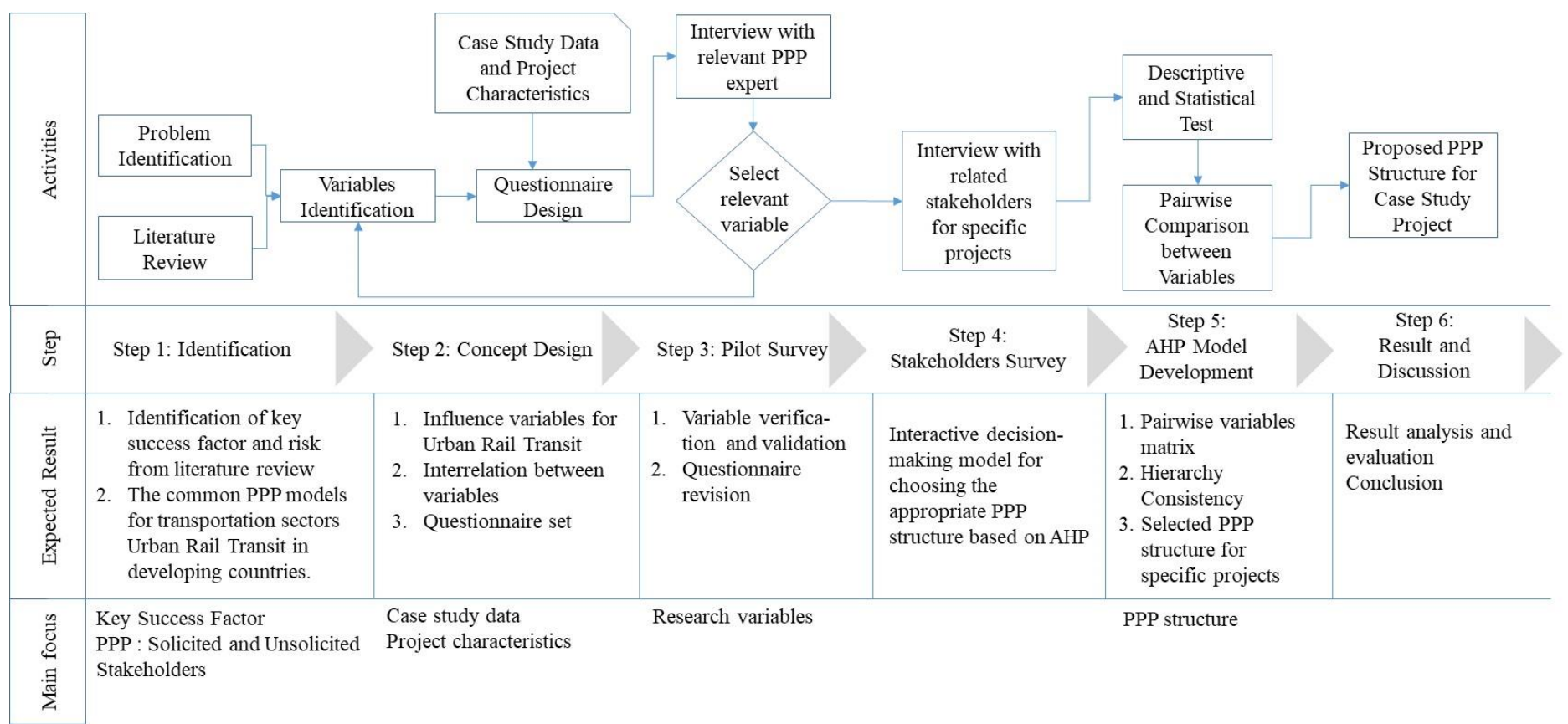

Fig. 3: Conceptual Framework to select a PPP Structure for Study Case of Urban Rail Transit

\section{Conclusion}

PPP unsolicited project has become an option for the private sector to participate and contribute in public service provision [5]. This scheme is often implemented in developing countries facing a lack of government's budget, experience, and technical ability to deliver and introduce technology innovation [49]. Therefore, this paper aims to propose a conceptual framework to guide the PPP stakeholders in selecting the appropriate using multi-tool AHP's decision-making criteria.

Research variables have been identified from the literature review and tested in a pilot survey by interviewing relevant PPP experts. These variables are pairwise compared with selected PPP models for urban rail transit, referring to the experience in the South East Asian countries [18]. This decision-making model is expected to suit the government's need to define the PPP structure for the proposed urban rail transit project as part of the evaluation process to accept the unsolicited PPP project proposed by the private sector. 


\section{Acknowledgments}

This paper was part of the evaluation process to the Unsolicited Proposal of the Jakarta Light Rail Transit Feasibility Study funded by the PT. Pembangunan Jaya and proposed to the Government of Jakarta, Indonesia. The authors thank all parties who have participated in data collection. All statements and interpretations in this study are the author's responsibility and only reflect the author's view.

\section{References}

[1] R. Osei-Kyei and A. P. C. Chan, "Review of studies on the critical success factors for public-private partnership (PPP) projects from 1990 to 2013," Int. J. Proj. Manag., vol. 33, no. 6, pp. 1335-1346, 2015, DOI: 10.1016/j.ijproman.2015.02.008.

[2] M. Hueskes, K. Verhoest, and T. Block, "Governing public-private partnerships for sustainability: An analysis of procurement and governance practices of PPP infrastructure projects," Int. J. Proj. Manag., vol. 35, no. 6, pp. 11841195, 2017, DOI: 10.1016/j.ijproman.2017.02.020.

[3] H. C. Silvestre and J. F. F. E. De Araújo, "Public-private partnerships/private finance initiatives in Portugal: Theory, practice, and results," Public Perform. Manag. Rev., vol. 36, no. 2, pp. 316-339, 2012, DOI: 10.2753/PMR15309576360208.

[4] M. A. Soomro and X. Zhang, "Evaluation of the Functions of Public Sector Partners in Transportation Public-Private Partnerships Failures," J. Manag. Eng., vol. 32, no. 1, Jan. 2016, DOI: 10.1061/(ASCE)ME.1943-5479.0000387.

[5] World Bank, "Policy guidelines for managing unsolicited proposals in infrastructure projects: Guidelines for the Development of A Policy for Managing Unsolicited Proposals in Infrastructure Projects - Volume II,” 2017.

[6] G. Castelblanco, J. Guevara, H. Mesa, and D. Flores, "Risk allocation in unsolicited and solicited road public-private partnerships: Sustainability and management implications," Sustain., vol. 12, no. 11, 2020, DOI: 10.3390/su12114478.

[7] J. T. Hodges and G. Dellacha, "Unsolicited infrastructure proposals," 2007.

[8] S. Y. Phang, "Urban rail transit PPPs: Survey and risk assessment of recent strategies," Transp. Policy, vol. 14, no. 3, pp. 214-231, 2007, DOI: 10.1016/j.tranpol.2007.02.001.

[9] Z. Chang and S. Y. Phang, "Urban rail transit PPPs: Lessons from East Asian cities," Transp. Res. Part A Policy Pract., vol. 105, no. September, pp. 106-122, 2017, DOI: 10.1016/j.tra.2017.08.015.

[10] T. Dolla and B. Laishram, "Bundling in public-private partnership projects - a conceptual framework," Int. J. Product. Perform. Manag., no. 2015, 2019, DOI: 10.1108/IJPPM-02-2019-0086.

[11] R. Osei-Kyei and A. P. C. Chan, "Factors attracting private sector investments in public-private partnerships in developing countries: A survey of international experts," J. Financ. Manag. Prop. Constr., vol. 22, no. 1, pp. 92-111, 2017, DOI: 10.1108/JFMPC-06-2016-0026.

[12] A. O. Mohammed and T. Harputlugil, "Conceptual Framework for a Decision-Making Model Based on the Analytic Hierarchy Process (Ahp) to Select the Best Public-Private Partnership (Ppp) Model for Airports," 3rd Nzaar Int. Event Ser. Nat. Built Environ. Cities, Sustain. Adv. Eng., no. March, pp. 99-107, 2017.

[13] S. Garg and S. Garg, "Rethinking Public-private Partnerships : An Unbundling Approach," Transp. Res. Procedia, vol. 25, pp. 3789-3807, 2017, DOI: 10.1016/j.trpro.2017.05.241.

[14] J. Delmon, "Understanding Options for Public-Private Partnerships in Infrastructure," 2010.

[15] J. Liu, R. Gao, C. Y. J. Cheah, and J. Luo, "Incentive mechanism for inhibiting investors' opportunistic behavior in PPP projects,” Int. J. Proj. Manag., vol. 34, no. 7, pp. 1102-1111, 2016, DOI: 10.1016/j.ijproman.2016.05.013.

[16] L. Bolaños, J. Gifford, and J. Y. Kweun, "Bankruptcy policy and surface transportation public-private partnerships: A comparative analysis of the U.S. and Europe," Case Stud. Transp. Policy, vol. 7, no. 2, pp. 185-195, 2019, DOI: 10.1016/j.cstp.2019.04.003.

[17] R. Osei-Kyei, A. P. C. Chan, A. Dansoh, J. K. Ofori-Kuragu, and G. D. Oppong, "Strategies for Effective Management of Unsolicited Public-Private Partnership Proposals," J. Manag. Eng., vol. 34, no. 3, pp. 1-12, 2018, DOI: 10.1061/(ASCE)ME.1943-5479.0000598.

[18] D. Bray and P. Sayeg, "Private sector involvement in urban rail: Experience and lessons from South East Asia," Res. 
Transp. Econ., vol. 39, no. 1, pp. 191-201, 2013, DOI: 10.1016/j.retrec.2012.06.013.

[19] World Bank, "Policy guidelines for managing unsolicited proposals in infrastructure projects: Main Findings and Recommendations," 2017.

[20] I. Kivleniece and B. V. Quelin, "Creating and Capturing Value in Public-Private Ties : A Private Actor's Perspective," Acad. Manag. Rev., vol. 37, no. 2, pp. 272-299, 2018.

[21] C. Cui, Y. Liu, A. Hope, and J. Wang, "Review of studies on the public-private partnerships (PPP) for infrastructure projects," Int. J. Proj. Manag., vol. 36, no. 5, pp. 773-794, 2018, DOI: 10.1016/j.ijproman.2018.03.004.

[22] S. Hong, "When does a public-private partnership (PPP) lead to inefficient cost management? Evidence from South Korea's urban rail system," Public Money Manag., vol. 36, no. 6, pp. 447-454, 2016, DOI: 10.1080/09540962.2016.1206755.

[23] Y. Liang and H. Jia, "Key Success Indicators for PPP Projects: Evidence from Hong Kong,” Adv. Civ. Eng., vol. 2018, 2018, DOI: $10.1155 / 2018 / 9576496$.

[24] J. Du, H. Wu, and L. Zhu, "Influencing Factors on Profit Distribution of Public-Private Partnership Projects: Private Sector's Perspective," Adv. Civ. Eng., vol. 2018, no. 1, 2018, DOI: 10.1155/2018/2143173.

[25] T. Liu, Y. Wang, and S. Wilkinson, "Identifying critical factors affecting the effectiveness and efficiency of tendering processes in Public-Private Partnerships ( PPPs ): A comparative analysis of Australia and China," vol. 34, pp. 20092011, 2016.

[26] R. Osei-Kyei and A. P. C. Chan, "Implementing public-private partnership (PPP) policy for public construction projects in Ghana: critical success factors and policy implications," Int. J. Constr. Manag., vol. 17, no. 2, pp. 113-123, 2017, DOI: $10.1080 / 15623599.2016 .1207865$.

[27] X. Zhang, "Critical success factors for public-private partnerships in infrastructure development," J. Constr. Eng. Manag., vol. 131, no. 1, pp. 3-14, Jan. 2005, DOI: 10.1061/(ASCE)0733-9364(2005)131:1(3).

[28] R. Osei-Kyei and A. P. C. Chan, "Comparative study of governments' reasons/motivations for adopting public-private partnership policy in developing and developed economies/countries," Int. J. Strateg. Prop. Manag., vol. 22, no. 5, pp. 403-414, 2018, DOI: 10.3846/ijspm.2018.5223.

[29] I. Kivleniece and B. V. Quelin, "Creating and Capturing Value in Public-Private Ties : A Private Actor's Perspective Source," Acad. Manag. Rev., vol. 37, no. 2, pp. 272-299, 2018.

[30] PPIAF, "Toolkit for Public-Private Partnerships in roads \& Highways," Public-Priv. Infrastruct. Advis. Facil., no. 1, p. 2, 2009.

[31] N. F. da Cruz and R. C. Marques, "Rocky road of urban transportation contracts," J. Manag. Eng., vol. 30, no. 5, pp. 110, 2014, DOI: 10.1061/(ASCE)ME.1943-5479.0000224.

[32] I. Demirag, I. Khadaroo, P. Stapleton, and C. Stevenson, "Risks and the financing of PPP: Perspectives from the financiers," Br. Account. Rev., vol. 43, no. 4, pp. 294-310, 2011, DOI: 10.1016/j.bar.2011.08.006.

[33] B. Ozorhona and S. Demirkesena, "Managing Risks in Public-Private Partnership Projects : The Case of Izmit Bay Suspension," no. 2016, 2015.

[34] K. M. Eisenhardt, "Linked references are available on JSTOR for this article: Agency Theory: An Assessment and Review," vol. 14, no. 1, pp. 57-74, 1989.

[35] S. K. Sundararajan and C. L. Tseng, "Managing Project Performance Risks under Uncertainty: Using a Dynamic Capital Structure Approach in Infrastructure Project Financing," J. Constr. Eng. Manag., vol. 143, no. 8, pp. 1-14, 2017, DOI: 10.1061/(ASCE)CO.1943-7862.0001341.

[36] V. S. Vasconcelos, F. Q. Silva, R. L. Rovai, M. de M. C. De Liberal, and C. D. A. Rached, "Identification of the main risk factors in infrastructure projects of transporting people on rail by public-private partnerships," Int. J. Entrep., vol. 23, no. 1, 2019.

[37] A. D. Ibrahim, A. D. F. Price, and A. R. J. Dainty, "The analysis and allocation of risks in public-private partnerships in infrastructure projects in Nigeria," J. Financ. Manag. Prop. Constr., vol. 11, no. 3, pp. 149-164, 2006, DOI: $10.1108 / 13664380680001086$.

[38] M. Poliak, Š. Semanová, and A. Poliaková, "Risk allocation in transport public service contracts," Ekon. Pregl., vol. 
66, no. 4, pp. 384-403, 2015.

[39] F. Yucelgazi and I. Yitmen, "Risk Assessment for Large-Scale Transport Infrastructure Projects," IOP Conf. Ser. Mater. Sci. Eng., vol. 471, no. 2, 2019, DOI: 10.1088/1757-899X/471/2/022005.

[40] L. Compagno, D. D’Urso, A. G. Latora, and N. Trapani, The value-analytic hierarchy process: A lean multi criteria decision support method, vol. 46, no. 9. IFAC, 2013.

[41] I. Paleie and B. Lalic, "Analytical hierarchy process as a tool for selecting and evaluating projects," Int. J. Simul. Model., vol. 8, no. 1, pp. 16-26, 2009, DOI: 10.2507/IJSIMM08(1)2.112.

[42] R. W. Saaty, "The analytic hierarchy process-what it is and how it is used," Math. Model., vol. 9, no. 3-5, pp. 161-176, 1987, DOI: 10.1016/0270-0255(87)90473-8.

[43] B. Farhang Moghaddam, A. A. Fatahi, P. Dokouhaki, and B. Ashtiani, "Qualitative Evaluation and Selecting the Optimum Public-Private Partnership System for Transportation," Int. J. Res. Ind. Eng., vol. 2, no. 2, pp. 61-69, 2013.

[44] F. Zahedi, "The Analytic Hierarchy Process-A Survey of the Method and its Applications," Interfaces (Providence)., vol. 16, no. 4, pp. 96-108, 1986, DOI: 10.1287/inte.16.4.96.

[45] E. Noorzai, K. G. Jafari, R. Heshmatnezhad, and B. Vahedi, "Implementing AHP Approach to Select an Appropriate Financing Method for PPP Highway Projects in Iran," Int. J. Struct. Civ. Eng. Res., vol. 5, no. 1, pp. 67-73, 2016, DOI: 10.18178/ijscer.5.1.67-73.

[46] H. Yan, C. Gao, H. Elzarka, K. Mostafa, and W. Tang, "Risk assessment for construction of urban rail transit projects," Saf. Sci., vol. 118, no. June, pp. 583-594, 2019, DOI: 10.1016/j.ssci.2019.05.042.

[47] S. Zhou and P. Yang, "Risk management in distributed wind energy implementing Analytic Hierarchy Process," Renew. Energy, vol. 150, pp. 616-623, 2020, DOI: 10.1016/j.renene.2019.12.125.

[48] D. Adom, E. K. Hussain, and A. A. Joe, "Theoretical and Conceptual Framework : Mandatory Ingredients of a Quality Research," Int. J. Sci. Res., vol. 7, no. 1, pp. 93-98, 2018.

[49] R. Osei-Kyei, A. P. C. Chan, A. Dansoh, J. K. Ofori-Kuragu, and E. K. Owusu, "Motivations for adopting unsolicited proposals for public-private partnership project implementation: A survey of international experts," J. Financ. Manag. Prop. Constr., vol. 23, no. 2, pp. 221-238, 2018, DOI: 10.1108/JFMPC-06-2017-0020. 